\title{
IMPLEMENTASI SUPERVISI KEPALA SEKOLAH TERHADAP KINERJA GURU DALAM UPAYA MENINGKATKAN KUALITAS PEMBELAJARAN DI MADRASAH IBTIDAIYAH NEGERI (MIN) KOTA BOGOR
}

\author{
Sarifudin \\ Dosen Tetap Prodi Manajemen Pendidikan Islam STAI AI Hidayah Bogor \\ email: sarifudin1182@gmail.com
}

Received: 21/01/2019, Accepted: 23/01/2019, Published: 28/01/2019

\begin{abstract}
At the moment there are still educational institutions whose governance is still not optimal. One of the successes of education is management carried out by the principal as the determinant of education policy. The principal is the most important element in the success of education, because the principal has a very important role in the success of education, the principal as a manager has the authority to carry out supervision activities on the performance of the teacher as the implementer of teaching and learning activities in the classroom. The purpose of this study is to describe the implementation of supervision carried out by school principals in improving teacher performance. Supervision activities carried out by the principal of the State Madrasah Ibtidaiyah (MIN) of Bogor City are by planning activities, namely by arranging supervision programs for one semester. The results of the study indicate that the implementation of supervision carried out by the Head of the MIN City of Bogor, among others: providing motivation to the teachers as the spearhead of success in educating students, conducting classroom visits, in the form of occasional observation activities. The next program in the principal's supervision activities is after conducting supervision in the classroom, and found several problems that need to be addressed, then after that followed up with individual talks between the principal and the teacher. The next activity was to conduct an evaluation of the supervision program carried out by the principal and assisted by the deputy head of the curriculum in the field towards the end of semester activities.
\end{abstract}

Keywords: implementation, headmaster, supervision, performance, quality of learning.

\section{ABSTRAK}

Pada saat ini masih ada lembaga pendidikan yang tata kelolanya masih belum maksimal. Salah satu keberhasilan pendidikan adalah manajemen yang dilakukan oleh kepala sekolah selaku penentu kebijakan pendidikan. Kepala sekolah merupakan elemen terpenting dalam keberhasilan pendidikan, karena kepala sekolah mempunyai peran yang sangat penting dalam keberhasilan pendidikan, kepala sekolah sebagai manajer memiliki wewenang dalam melaksanakan kegiatan supervisi terhadap kinerja guru sebagai pelaksana kegiatan belajar mengajar di kelas. Tujuan penelitian ini adalah untuk mendeskripsikan implementasi supervisi yang dilakukan oleh kepala sekolah dalam meningkatkan kinerja guru. Kegiatan supervisi yang dilakukan oleh kepala sekolah Madrasah Ibtidaiyah Negeri (MIN) Kota 
Bogor adalah dengan melakukan perencanaan, dengan menyusun program-program supervisi selama satu semester. Adapun hasil penelitian menunjukkan bahwa implementasi supervisi yang dilakukan oleh Kepala Sekolah MIN Kota Bogor, antara lain: memberikan motivasi kepada para guru sebagai ujung tombak keberhasilan dalam mendidik murid, melakukan kegiatan kunjungan ke kelas, berupa kegiatan observasi yang sesekali dilakukan. Program selanjutnya dalam kegiatan supervisi kepala sekolah adalah setelah melakukan supervisi di kelas, dan didapati berberapa permasalahan yang perlu disampaikan, maka setelah itu ditindaklanjuti dengan pembicaraan individual antara kepala sekolah dan guru. Kegiatan selanjutnya adalah melakukan evaluasi dari program supervisi yang dilakukan oleh kepala sekolah dan dibantu oleh wakil kepala sekolah bidang kurikulum menjelang berakhirnya kegiatan semesteran.

\section{A. PENDAHULUAN}

Pada saat ini setiap bangsa berlomba-lomba untuk dapat meningkatkan kualitas pendidikan masyarakatnya, karena dengan pendidikan dapat meningkatkan peradaban bangsa yang bersangkutan menjadi bangsa yang bermartabat. Pendidikan adalah upaya sistematis yang dilakukan secara bersama-sama. Sebagaimana dijelaskan dalam undang-undang Nomor 20 tahun 2003 berkaitan dengan sistem pendidikan Nasional dijelaskan bahwa guru merupakan tenaga profesional yang mempunyai tugas yaitu sebagai perencana serta pelaksana proses pembelajaran, penilai hasil pembelajaran, melakukan bimbingan dan pelatihan, dan melakukan kegiatan penelitian dan pengabdian pada masyarakat, terutama bagi pendidik pada tingkat perguruan tinggi yang tercantum pada pasal 39 ayat 1 (Abdul Wahab H.S. dan Umiarso, 2011: 118).

Peran guru sangatlah besar, begitu besar peran guru sehingga tokoh-tokoh pendidikan ada yang berpendapat bahwa sebagus apapun kurikulumnya dan selengkap apapun sarana prasarana tidak akan bermanfaat tanpa adanya guru yang berkualitas. (Agus Wibowo dan Hamrin, 2012: 5). Guru memiliki peran yang sakral dan penting dalam mencapai keberhasilan tujuan pendidikan. Oleh sebab itu, setiap adanya perubahan yang bertujuan mengarah kepada perbaikan dalam dunia pendidikan, khususnya pada kurikulum serta peningkatan sumber daya manusia yang dihasilkan dari upaya pendidikan pasti bermuara pada faktor dari seorang guru. Sehingga dapat disimpulkan bahwa keberadaan guru memiliki pengaruh yang sangat besar pada dunia pendidikan (Moh. 
Uzer Usman, 2009: 5). Selain itu, dalam mendukung kinerja guru harus mempunyai karakter agar bisa berkonsultasi dengan orang lain, karena seorang guru membutuhkan dorongan berupa motivasi dari orang lain, dalam hal ini kepala sekolah. Kadang seorang guru dihadapkan masalah-masalah berpolemik dan perkara-perkara rumit yang membingungkan dan tidak ditemukan penyelesaian dan solusinya (Fu'ad bin Abdul Aziz Asy Syalhub, 2011: 49).

Oleh sebab itu, perlu adanya suatu pengolahan terhadap kinerja guru yaitu berupa kegiatan supervisi. Melalui pengawasan, sosialisasi, dan pelatihan guru diharapkan memiliki kompetensi sebagai pedoman dalam mengajar serta telah memiliki keterampilanketerampilan dalam mengajar seperti: guru memiliki paradigma baru yaitu guru bukan lagi merupakan pusat dan sumber belajar utama bagi siswa karena masih ada sumber belajar lainnya seperti buku, perpustakaan, lingkungan sekitarnya atau mungkin siswa sendiri, bervariasi dalam menggunakan metode pembelajaran seperti ceramah, diskusi, demontrasi, dan pemberian tugas.

Kegiatan pengawasan adalah fungsi terakhir dari kegiatan manajemen yaitu fungsi controlling, pengertian pengawasan dapat diartikan sebagai suatu proses untuk menjamin bahwa tujuan-tujuan yang sudah direncanakan oleh organisasi dan manajemen agar dapat tercapai dengan baik dan maksimal (Connie Charirunnisa, 2016: 215). Akan tetapi pada saat sekarang ini masih ada suatu lembaga pendidikan yang gurunya masih belum bisa mengembangkan potensi dari guru tersebut dalam hal kinerja seorang guru dalam melaksanakan tugas pendidikan. Sehingga masih ada permasalahan yang terkait dengan rendahnya tingkat perilaku guru, seperti para guru umumnya yang sering dianggap kurang kreatif dalam melaksanakan kegiatan pengajaran terhadap para peserta didik, sehingga para peserta didik sering merasa jenuh dengan pelajaran yang bersangkutan. Adanya kecenderungan para guru melaksanakan tugas mengajarnya hanya sekedar memenuhi kewajibannya mengajar tanpa adanya dorongan untuk membuat peserta didiknya mengerti atau memahami tentang apa yang mereka ajarkan. Masih sering terjadi adanya guru yang datang terlambat dalam memberikan pengajaran terhadap peserta didiknya, sehingga hal ini akan mengakibatkan para peserta didik kehilangan sebagian 
waktu belajar dan memberikan kesempatan mereka gaduh di kelas, dan membuat suasana kelas menjadi tidak kondusif. Masih terdapatnya guru yang tidak berhasil mencapai target penyampaian materi sesuai dengan kurikulum yang berlaku, sehingga para peserta didik kehilangan beberapa materi yang tidak sempat diajarkan. Hal ini akan mengakibatkan kerugian bagi para peserta didik karena ilmu yang seharusnya mereka dapatkan dari hasil belajar mereka tidak sesuai harapan yang mereka inginkan. Adanya kecenderungan merosotnya semangat para guru, sehingga membawa dampak terhadap kegiatan belajar menjadi tidak kondusif.

Oleh karena itu perlu adanya stimulus dari kepala sekolah sebagai seorang manajer, agar guru tersebut dapat mengembangkan kinerjanya. Maka dituntut perlu adanya programprogram inovasi yang dilakukan kepala sekolah agar dapat meningkatkan dan memaksimalkan kinerja guru, inovasi sendiri adalah kemampuan menciptakan, atau menggunakan keahlian dan kemampuan dalam melakukan suatu pengembangan suatu pekerjaan tertentu (Muhammad Abdul Jawwad, 2004: 8).

Dari pembahasan di atas, maka tentang realita keadaan dunia pendidikan, terutama di lembaga pendidikan perlu diadakan suatu penelitian yang ilmiah terhadap pembahasan tentang implementasi pelaksanaan supervisi seorang kepala sekolah terhadap kinerja guru di suatu lembaga pendidikan.

\section{B. KAJIAN TEORITIS}

\section{Pembahasan Supervisi}

a. Definisi Supervisi

Ara Hidayat dan Imam Machali berpendapat bahwa secara etimologi supervisi berasal dari kata "super" dan "vision", super bisa bermakna kelebihan, orang yang mempunyai kelebihan jika dibandingkan orang lain, sedangkan vision bermakna sebagai pandangan jauh ke depan (2012: 111). Sedangkan menurut (E. Mulyasa, 2012: 239) secara bahasa supervisi berasal dari kata "super" dan "visi" yang bermakna melihat dan meninjau dari atas atau menilik dan menilai dari atas, maksudnya adalah kegiatan yang dilakukan oleh seorang atasan terhadap seluruh kegiatan berupa aktivitas, kreativitas dan kinerja yang dilakukan oleh bawahannya.

Dalam istilah kata lain terdapat beberapa kata yang hampir sama bermakna supervisi, kata tersebut bahkan dalam pelaksanaannya katakata tersebut sering digunakan secara 
bergantian kata-kata tersebut adalah pengawasan, pemeriksaan, dan inspeksi. Kata pengawasan memiliki makna suatu pekerjaan untuk melakukan pengamatan agar pekerjaan dilakukan sesuai dengan ketentuan yang berlaku. Pemeriksaan dapat diartikan untuk melihat bagaimana kegiatan yang dilaksanakan telah mencapai sesuai tujuan. Adapun inspeksi dapat ditujukan untuk mengetahui kekurangan-kekurangan atau kesalahan-kesalahan yang harus diperbaiki secepat mungkin dalam suatu kegiatan yang telah dilaksanakan. Memahami deskripsi di atas, sebenarnya kata-kata tersebut identik dengan supervisi sehingga wajar kalau dalam penggunaannya sering dipertukarkan. (E. Mulyasa, 2012: 239).

Maksud dari inti supervisi pendidikan yang dilakukan oleh kepala seorang sekolah sejalan yang dikatakan oleh Cicih Sutasih, bahwa pada umumnya mengacu pada usaha perbaikan situasi belajar mengajar, hakikatnya supervisi pendidikan dapat didefinisikan sebagai kegiatan bimbingan profesional yang dilakukan oleh kepalah sekolah terhadap guruguru. Bimbingan dimaksudkan adalah segala kegiatan yang dilakukan oleh kepala sekolah yaitu memberikan bimbingan agar para guru mimiliki kesempatan untuk berkembang secara profesional, sehingga mereka menjadi lebih bersemangat dalam melaksanakan tugas pokoknya, yaitu memperbaiki dan meningkatkan kualitas proses belajar siswa (Tim Dosen UPI, 2011: 312-313).

Pada umumnya pelaksanaan supervisi memiliki beberapa kegiatan pokok, yaitu pembinaan yang berjalan terus menerus, kegiatan peningkatan kemampuan profesional personil guru, perbaikan situasi kegiatan belajarmengajar di kelas dengan sasaran akhir yang maksimal dengan pencapaian tujuan pendidikan dan pertumbuhan pribadi peserta didik yang unggul. Dengan kata lain, dalam kegiatan supervisi adanya suatu proses pelayanan yang dilakukan oleh kepala sekolah untuk membantu atau membina para dewan guru, pembinaan ini diharapkan menimbulkan perbaikan atau peningkatan kemampuan profesional seorang guru. Sehingga perbaikan dan peningkatan kemampuan yang didapat oleh seorang guru dapat direalisasikan ke dalam perilaku mengajar di kelas sehingga terbentuknya situasi belajar-mengajar yang lebih baik dan maksimal, yang akhirnya juga dapat meningkatkan 
kualitas perkembangan peserta didik. (E. Mulyasa, 2012: 241).

b. Tujuan Supervisi

Tujuan dari kegiatan supervisi berdasarkan pengertian dan hakikatnya seperti dijelaskan di atas dapat di tarik kesimpulan bahwa bertujuan untuk mengembangkan suasana yang kondusif dan lebih baik dalam kegiatan belajar-mengajar di kelas, melalui kegiatan pembinaan serta peningkatan profesi mengajar guru. Dengan kata lain, tujuan supervisi pengajaran adalah untuk membantu dan memberikan kemudahan kepada para guru untuk belajar bagaimana meningkatkan kemampuan mereka guna mewujudkan tujuan belajar peserta didik yang dicitacitakan. (E. Mulyasa, 2012: 241).

Tujuan lain dari kegiatan supervisi sebagaimana dijelaskan oleh E. Mulyasa mengutip pendapat Ametembun (1981), bahwa tujuan supervisi yaitu (1) Membina kepala sekolah sebagai atasan dan guru-guru sebagai bawahan untuk lebih memahami bagaimana tujuan pendidikan yang sebenarnya dan lembaga sekolah diharapkan dapat memiliki peranan dalam merealisasikan tujuan tersebut; (2) Meningkatkan kesanggupan seorang kepala sekolah dan dewan guru dalam melaksanakan tugasnya yaitu untuk mempersiapkan para siswa agar menjadi calon anggota masyarakat yang lebih efektif dan unggul; (3) Tujuan lainnya adalah membantu seorang kepala sekolah dan guru dalam mengadakan pengamatanpengamatan secara kritis dan akurat terhadap seluruh aktivitas-aktivitas yang dikerjakan dan kesulitan-kesulitan belajar-mengajar di kelas, serta menolong kepala sekolah dan guru dalam merencanakan perbaikanperbaikan; (4) Menumbuhkan rasa tanggungjawab dan rasa kesadaran kepala sekolah dan dewan guru serta pegawai sekolah lain terhadap cara kerja yang demokratis dan komprehensif, serta memperbesar kesediaan untuk tolong-menolong antar sesama; (5) Menumbuhkan rasa semangat guru-guru dan menumbuhkan motivasi berprestasi untuk mengoptimalkan kinerja guru secara maksimal dalam melaksanakan profesinya sebagai seorang guru; (6) Membantu kepala sekolah untuk mempopulerkan peningkatkan program-program pendidikan di sekolah kepada masyarakat; (7) Tujuan lainnya yaitu melindungi orang-orang yang disupervisi oleh kepala sekolah terhadap tuntutan-tuntutan yang tidak wajar dan kritik-kritik yang tidak sehat dari masyarakat sekitar; (8) Membantu kepala sekolah dan guru dalam 
mengevaluasi kegiatannya untuk mengembangkan aktivitas dan kreativitas peserta didik agar lebih maju; dan (9) Meningkatkan rasa kesatuan dan persatuan antar sesama guru (E. Mulyasa, 2012: 242-244).

\section{Supervisor Pendidikan dalam} Diri Kepala Sekolah

a. Kepala Sekolah sebagai Supervisor Pendidikan

Wahjo Sumidjo (2002: 83 ). mengartikan kepala sekolah dalam bukunya Kepemimpinan Kepala Sekolah adalah kepala sekolah terdiri dari dua kata, yaitu kepala dan sekolah. Kata kepala dapat didefinisikan sebagai ketua atau pemimpin dalam sebuah organisasi atau sebuah lembaga pendidikan. Sedangkan sekolah adalah sebuah lembaga pendidikan di mana menjadi tempat yang menyelenggarakan kegiatan menerima dan memberi pelajaran. Dengan demikian dapat disimpulkan bahwa kepala sekolah dapat diartikan "sebagai seorang tenaga fungsional guru yang diberi tugas untuk memimpin suatu sekolah dimana diselenggarakan proses belajar mengajar, atau tempat di mana terjadi interaksi antara guru yang memberi pelajaran dan murid yang menerima pelajaran".
Kepala sekolah sebagai pemimpin dalam lembaga pendidikan harus mempunyai perilaku yang efektif dalam memimpin suatu lembaga pendidikan, seperti merencanakan dan mengorganisasikan, mengidentifikasi masalah, menjelaskan peran dan sasaran, memberi informasi, memonitoring, memotivasi, berkonsultasi, mendelegasikan, memberikan dukungan, membimbing, mengelolah konplik dan membangun tim, membangun jaringan kerja, memberi pujian, dan memberikan imbalan (Kompri, 2015: 326-328).

Kegiatan supervisi merupakan kegiatan yang sangat urgen dilakukan oleh kepala sekolah sebagai visitator. Hal ini sejalan dengan Jamal Ma'mur Ma'ruf Asmani dalam bukunya yang mengatakan bahwa supervisi merupakan kegiatan yang dilakukan oleh seorang kepala sekolah dalam membina dan membantu meningkatkan kualitas kinerja setiap orang (guru) agar mengalami peningkatan pribadi yang berprofesi yang unggul, supervisi merupakan usaha yang dilakukan oleh kepala sekolah dalam memberikan layanan bimbingan kepada para guru baik secara individual (pribadi) maupun secara kelompok dalam usaha memperbaiki proses pengajaran dengan tujuan memberikan layanan 
dan bantuan untuk meningkatkan suasana belajar mengajar yang dilakukan guru terhadap para siswa di kelas (Jamal Ma'mur Asmani, 2012: 188).

Kegiatan pokok pendidikan di sekolah dalam rangka melaksanakan tujuannya adalah kegiatan pembelajaran, sehingga seluruh kegiatan aktivitas organisasi sekolah berpusat pada pencapaian efisiensi dan efektivitas pembelajaran yang direncanakan sebelumnya. Oleh karena itu, salah satu tugas pokok dari kepala sekolah adalah sebagai supervisor pendidikan, yaitu bertugas untuk mensupervisi kinerja yang dilakukan oleh para tenaga kependidikan. (E. Mulyasa, 2012: 252). Maksud dari pembahasan kepala sekolah sebagai supervisor adalah kepala sekolah bertugas mensupervisi yaitu melakukan pengawasan terhadap pekerjaan guru-guru dan pegawaipegawai sekolahnya. Supervisi adalah suatu kegiatan menentukan kondisi dan syarat-syarat yang penting yang akan menjamin terlaksananya tujuan-tujuan pendidikan pada sebuah lembaga pendidikan. Sehingga disimpulkan bahwa tugas seorang kepala sekolah sebagai supervisor berarti bahwa dia hendaknya mahir dalam meneliti, menggalih, dan menentukan syarat- syarat mana sajakah yang sangat diperlukan bagi kemajuan suatu lembaga pendidikan sehingga tujuantujuan pendidikan di lembaga pendidikan itu semaksimal mungkin dapat dicapai dengan baik. la harus bisa meneliti dan menentukan syaratsyarat apa saja yang ada dan syaratsyarat tersebut harus dipenuhi dengan baik. Kepala sekolah yang yang dapat dikatakan ideal adalah ia harus memiliki kelebihan-kelebihan jika dibandingkan dengan orang yang dipimpinnya, kepala sekolah harus bisa menggerakkan orang yang di pimpinnya (Sudarwan Danim, 2015: 205).

Untuk mengetahui kemampuan seorang guru mampu melaksanakan pembelajaran, maka seorang kepala sekolah diwajibkan secara berkala dan terencana untuk melakukan kegiatan supervisi yaitu dengan melihat langsung seorang guru sedang mengajar, hal ini dapat dilakukan melalui kegiatan kunjungan ke kelaskelas untuk melihat dan mengamati kegiatan proses belajar mengajar di kelas (Agustinus Hermino, 2014: 144). Posisi kepala sekolah sebagai seorang pemimpin lembaga pendidikan hendaknya ia bisa memberikan contoh yang baik sehingga menjadi petunjuk anggotanya untuk dapat diikuti dalam 
kebaikan sehingga menjadi pembimbing mereka kepada hal kebenaran, begitu pula pemimpin rumah tangga harus bertanggung jawab atas pendidikan anak-anaknya dan mengarahkan kepada kebaikan (Thariq M. As Suwaidan dan Faisal Umar Basyarahil, 2005: 9).

Seorang kepala sekolah sebagai seorang manajer pendidikan harus meneliti bagaimana keadaan fasilitas seperti gedung sekolah, perlengkapanperlengkapan sekolah dan alat-alat pelajaran, dan juga dapat meneliti keadaan guru-guru, semangat kerja guru-guru dalam mengajar di kelas dan pegawai sekolah selain guru, cara mengajar guru-guru, hasil pelajaran dan pendidikan anak-anak, usaha yang dilakukan untuk memperbaiki dan meningkatkan cara kerja dan mutu guru-guru, prilaku dan perasaan tanggung jawab guru-guru dalam partisipasi terhadap pembinaan dan kemajuan peserta didik. (Ngalim Purwanto, 2010: 115-116).

Sebagai supervisor pendidikan, kepala sekolah harus bisa melakukan berbagai kegiatan seperti pengawasan dan pengendalian untuk meningkatkan kinerja para guru. Kegiatan pengawasan dan pengendalian ini merupakan cara agar kegiatan pendidikan di yang dilakukan di sekolah terarah sesuai tujuan yang telah ditetapkan sebelumnya. Kegiatan tersebut (pengawasan dan penegndalian) juga dapat disebut sebagai tindakan preventif yang bertujuan agar mencega para tenaga kependidikan tidak melakukan kesalahan dan agar lebih berhati-hati dalam melaksanakan tugas pekerjaannya.

b. Tugas dan Fungsi Kepala Sekolah dalam Supervisi

Tugas seorang kepala sekolah sebagai supervisor adalah tugas yang mesti dilaksanakan demi terwujudnya tujuan dari pendidikan. Kepala sekolah dalam mensupervisi kinerja guru pada intinya adalah membantu guru agar meningkatkan potensinya secara optimal. Hal ini sejalan dengan $E$. Mulyasa yang mengemukakan pendapat Gwyn yang dikutip Sahertian, yang merumuskan sepuluh tugas pokok supervisor, yaitu: (1) Agar guru bisa mengerti dan memahami keinginan para siswa; (2) Agar para guru bisa mengembangkan dan memperbaiki kesalahan baik secara pribadi maupun secara kelompok; (3) Agar bisa membantu para guru untuk lebih efektif dalam melaksanakan Kegiatan belajar-mengajar di kelas; (4) Dapat membantu para guru agar 
meningkatkan cara mengajar yang efektif dan benar; (5) Dapat membantu guru secara individual atau pribadi; (6) Bisa membantu guru agar dapat menilai para siswa; (7) Agar menstimulasi guru untuk dapat menilai diri dan pekerjaannya; (8) Membantu para guru agar merasa selalu bersemangat dalam melaksanakan tugasnya dengan penuh tanggungjawab; (9) Membantu dewan guru untuk dapat menerapkan kurikulum pendidikan di sekolah; dan (10) Mempermudah para guru untuk dapat memberikan informasi yang seluas-luasnya kepada masyarakat tentang keberadaan sekolah dan prestasinya (Ngalim Purwanto, 2010: 118).

Adapun fungsi kepala sekolah dalam supervisi secara umum adalah melakukan usaha-usaha antara lain: (1) Menumbuhkan dan merangsang para guru dan pegawai sekolah lainnya agar dapat menjalankan tugas yang diamanahinya dengan maksimal mungkin; (2) Mengusahakan pengadaan alat-alat perlengkapan sarana prasarana yang diperlukan yang bertujuan untuk membantu kelancaran proses belajar mengajar di lembaga tersebut; (3) Bekerjasama dengan para guru untuk mengembangkan, mencari dan menggunakan metode-metode mengajar yang lebih tepat sesuai dengan tuntutan kurikulum yang berlaku; (4) Terbinanya kerja sama yang baik dan harmonis di antara dewan guru dan para pegawai sekolah lainnya; (5) Meningkatkan mutu dan pengetahuan para guru dan para pegawai sekolah, seperti: mengadakan diskusi-diskusi terstruktur, mengadakan perpustakaan sekolah, atau mengutus para guru dan pegawai lainnya untuk mengikuti kegiatan pelatihan-pelatihan, seminar, sesuai dengan yang dibutuhkan; dan (6) Diharapkan terwujudnya hubungan kerja sama yang baik antara pihak sekolah dengan pihak Persatuan Orang Tua Murid dan Guru (POMG) atau komite sekolah dan instansi-instansi lain dalam rangka mewujudkan peningkatan mutu pendidikan para siswa (Ngalim Purwanto. 2010: 119).

c. Teknik Supervisi Kepala Sekolah

Teknik supervisi yang dilakukan oleh kepala sekolah secara garis besar, dapat dikelompokan menjadi dua, yaitu dengan cara perseorangan maupun kelompok. Teknik supervisi perseorangan adalah supervisi yang dilaksanakan secara perseorangan, seperti: (1) Mengunjungi kelas (classroom visitation), kegiatan ini dilakukan dengan cara mengunjungi kelas yang dilakukan oleh seorang 
kepala sekolah untuk melihat atau mengamati kegiatan seorang guru yang sedang mengajar di dalam kelas, maksudnya adalah untuk mengobservasi bagaimana cara seorang guru mengajar, apakah sudah memenuhi syarat-syarat yang diinginkan. Dengan maksud, untuk mengetahui apa saja kelebihan dan kekurangan, sehingga kekurangan tersebut agar dapat diperbaiki di kemudian hari; (2) Adapun teknik selanjutnya adalah teknik kunjungan observasi (observation visits), yaitu dengan cara menghadirkan para guru untuk mengamati salah satu guru yang sedang mempraktekkan cara-cara mengajar dengan baik dan benar; dan (3) Membimbing para guru tentang bagaimana cara mempelajari pribadi peserta didik dan memberikan solusi terhadap masalah-masalah yang dihadapi oleh para siswa. Membimbing dewan guru dalam hal yang berkaitan dengan kurikulum sekolah. seperti: menyusun program semesteran, catur wulan, membuat administrasi pengajaran (satuan pelajaran), dapat mengorganisasikan kegiatan pengelolaan di kelas, melaksanakan teknik-teknik evaluasi pengajaran, menggunakan sarana atau dan sumber dalam proses belajar mengajar di kelas, mengorganisasi kegiatan- kegiatan siswa dalam bidang ekstrakurikuler, study tour, dan kegiatan-kegaitan lainnya.

Adapun maksud dari teknik kelompok adalah supervisi yang dilakukan secara berkelompok, contohnya seperti mengadakan rapat atau pertemuan yang berkaitan dengan supervisi dan mengadakan diskusi kelompok (group discussions). Diskusi kelompok dapat dilaksanakan dengan membentuk kelompok-kelompok guru bidang studi yang linear atau sejenis, lalu diprogramkan untuk mengadakan pertemuan atau diskusi guna membicarakan hal-hal yang berhubungan dengan usaha pengembangan dan peranan proses belajar mengajar. Mengadakan penataran-penataran (inservice-training) misalnya penataran yang diperuntukan untuk guru-guru bidang studi tertentu, seperti penataran tentang metodologi pengajaran, dan penataran tentang administrasi pendidikan. (Ngalim Purwanto, 2010: 120).

\section{Pelaksanaan Supervisi untuk Meningkatkan Kinerja Guru Terhadap Kualitas Pembelajaran}

Maksud dari kinerja guru adalah melaksanakan seluruh proses pembelajaran yang dilakukan oleh seorang guru, baik yang ia lakukan di 
dalam kelas maupun yang ia lakukan di luar kelas, seperti mengerjakan administrasi sekolah, administrasi pembelajaran, melaksanakan bimbingan terhadap siswa dan layanan pada para siswa yang membutuhkan, serta melaksanakan penilaian terhadap hasil pembelajaran (Tabrani Rusyan et.al, 2000: 17). Posisi kepala sekolah dalam organisasi sekolah menempati posisi sebagai seorang manajer. Kepala sekolah memiliki posisi utama dan strategis, dia memegang kunci keberhasilan dalam mencapai tujuan yang telah ditentukan oleh lembaga pendidikan, kondisi tersebut menunjukan bahwa seorang kepala sekolah sebagai penentu kebijakan jasa suatu bidang professional dalam dunia pendidikan (Rohiat, 2012: 33). Pelaksanaan supervisi sangat diperlukan dalam kegiatan pendidikan, karena supervisi berkaitan dengan dua hal penting, pertama semakin berkembangnya kurikulum mencirikan kemajuan pendidikan, perkembangan kurikulum sering sekali menimbulkan perubahan-perubahan struktur maupun fungsi kurikulum, pelaksanaan kurikulum memerlukan penyesuaian yang terus menerus dengan keadaan yang nyata di lapangan, sehingga para guru harus senantiasa berusaha mengembangkan kreativitasnya agar supaya pendidikan berdasarkan kurikulum itu dapat terlaksana dengan baik. Kedua, pengembangan personel, dalam hal ini kepala sekolah, guru, dan tenaga kependidikan lainya memerlukan peningkatan karier, pengetahuan, dan keterampilanya. Pengembangan personel ini dapat dilakukan secara formal maupun informal, pengembangan formal dapat diselenggarakan dan menjadi tanggungjawab lembaga pendidikan, seperti penataran, lokakarya, tugas belajar dengan peningkatan pendidikan Adapun pengembangan informal menjadi tanggung jawab pegawai itu sendiri yang dilakukan secara mandiri atau bersama-sama dengan para rekan kerjanya (H. M. Daryanto, 2001: 173174).

Jadi tujuan utama dari supervisi yang dilakukan oleh kepala sekolah adalah untuk meningkatkan kemampuan profesional seorang guru dalam meningkatkan kualitas pembelajaran di kelas melalui pembelajaran yang baik dan terencana, karena faktor-faktor yang mempengaruhi prestasi kerja adalah salah satunya supervisi (Edy Sutrisno. 2017: 151-152). Menurut Surya, motivasi sangat urgent demi keberlangsungan organisasi atau lembaga pendidikan, karena orang- 
orang (guru) harus diberikan motivasi untuk bekerja sama antar satu dengan yang lain dalam lingkungan organisasi tersebut, selain itu pegawai (guru) harus senantiasa dimotivasi dan dituntut untuk bekerja secara maksimal dan berusaha sesuai tuntutan kerja dan tugasnya, sehingga motivasi merupakan suatu hal yang sangat penting dalam memelihara, menjaga dan meningkatkan sumber daya manusia dalam organisasi tersebut (KH. U. Saefullah, 2012: 257). Sikap dan perilaku terkait dengan atasanya, di antaranya adalah: (a) seorang guru yang baik ia suka memberikan ide dan masukan kepada atasan atas programprogram yang ada, seorang guru hendaknya mampu menjalin kerjasama dengan atasannya dalam hal ini kepala sekolah, guru juga harus bahu membahu dengan teman sesama guru dalam mensukseskan kegiatan yang ada dalam dunia pendidikan demi meningkatkan dan mengembangkan kualitas sumber daya manusia yang akan datang; dan (b) Guru yang baik hendaknya ia mendukung seluruh program atasannya, dengan catatan dukungan tersebut dilakukan dengan positif dan dalam suasana positif pula. (Soejitno Irmin-Abdul Rochim, 2004: 100-103).
Maksud dari kualitas pembelajaran adalah mutu pembelajaran atau juga bisa disebut keefektifan pembelajaran. Secara definitif efektivitas dapat diartikan sebagai tingkat keberhasilan pembelajaran dalam mencapai tujuan atau sasaran yang telah ditentukan sebelumnya. Kualitas menunjuk pada kemampuan riil (nyata) yang dimiliki oleh para siswa setelah mereka selesai mengikuti suatu tahapan pembelajaran, yang sering kali diwujudkan dalam nilainilai angka pada rapor peserta didik, atau dalam bentuk lain yang serupa. (Bedjo Sujanro, 2007: 123).

Kegiatan pembelajaran merupakan serangkaian kegiatan yang telah direncanakan oleh seorang guru untuk memungkinkan terjadinya suatu proses belajar pada siswa di kelas. Pembelajaran adalah sebagai suatu sistem atau proses membelajarkan siswa yang telah direncanakan oleh seoarang guru, dilaksanakan dan di evaluasi secara sistematis dan menyeluruh agar proses pembelajar dapat mencapai tujuan yang diinginkan yaitu pembelajaran secara aktif, efektif, dan inovatif. Pembelajaran atau pengajaran menurut Degeng adalah upaya untuk membelajarkan siswa. Dalam pengertian ini secara implisit kegiatan pengajaran terdapat beberapa kegiatan yaitu memilih, menetapkan, 
mengembangkan metode untuk mencapai hasil pengajaran yang diinginkan oleh seorang tenaga pengajar. (Hamzah, 2011: 2).

Menurut Gultom (2013), yang dimaksud dengan kualitas pembelajaran dilihat dari aktivitas para siswa ketika belajar di kelas dan kreativitas-kreativitas yang dilakukan oleh peserta didik setelah mereka mengikuti kegiatan pembelajaran di kelas. (Ridwan Abdullah Sani, 2014: 43). Untuk melihat kualitas pembelajaran, desain pembelajaran yang harus dilakukan adalah berdasarkan pada pendekatan sistem, akan memberikan peluang yang lebih besar dalam mengintegrasikan semua variabel yang dapat mempengaruhi belajar siswa, termasuk keterkaitan antar variabel pengajaran yaitu variabel kondisi pembelajaran, variabel metode, dan variabel hasil pembelajaran di kelas. (Ridwan Abdullah Sani, 2014): 5).

\section{METODOLOGI PENELITIAN}

Dalam menyelesaikan penelitian ini, peneliti menggunakan metode pendekatan kualitatif deskriptif, dengan tempat penelitian di Madrasah Ibtidaiyah Negeri (MIN) Kota Bogor sebagai sebuah lembaga pendidikan setingkat Sekolah Dasar yang bercirikan Islam, yang berlokasi Jalan
Sindang Barang Pengkolan No.23 RT.01/04 Kel. Sindang Barang Kec. Bogor Barat - Kota Bogor 16117 Telp. (0251) 8316905. Sumber data primer dari penelitian ini adalah berasal dari wawancara dengan pihak-pihak terkait seperti kepala sekolah dan dewan guru (MIN) Kota Bogor. Sedangkan data sekunder ialah sumber yang mendukung serta hubungan penelitian yang dibahas dimana sumber data sekunder dalam penelitian ini diantaranya bersumber dari buku-buku, dokumentasi, dan kepustakaan sumber-sumber lainnya yang mendukung serta berkaitan dengan masalah dalam penelitian tersebut. Selain wawancara, dalam penelitian ini peneliti mengumpulkan data dengan menggunakan kegiatan observasi dan studi dokumentasi yang semua datadata tersebut berasal dari pengamatan di (MIN) Kota Bogor.

\section{HASIL PENELITIAN DAN} PEMBAHASAN

Berdasarkan hasil wawancara terhadap kepala sekolah Madrasah Ibtidaiyah Negeri (MIN) Kota Bogor, dapat disimpulkan bahwa dalam melaksanakan kegiatan supervisi terhadap kinerja guru, kepala sekolah melakukan beberapa kegiatan, seperti: 
perencanaan supervisi, pelaksanaan supervisi dan evaluasi supervisi. Kegiatan perencanaan supervisi ini dilakukan ketika memasuki awal tahun ajaran baru, kepala sekolah MIN Kota Bogor melakukan perancanaan ini dibantu oleh Wakil Kepala Sekolah Bidang Kurikulum. Dalam kegiatan perancanaan ini kepala sekolah MIN Kota Bogor menyusun programprogram supervisi selama satu semester, adapun programprogramnya sebagai berikut: melaksanakan program rapat awal tahun ajaran baru, pada awalnya kepala sekolah sebagai visitator mengeluarkan surat edaran berkaitan dengan kegiatan rapat tersebut. Pada kegiatan ini kepala sekolah memberikan motivasi kepada para guru sebagai ujung tombak keberhasilan dalam mendidik murid. Kepala Sekolah (MIN) kota Bogor sebagai pimpinan tertinggi biasanya wajib melakukan kegiatan rutinitas berupa rapat semseteran, kegiatan ini biasanya dilakukan oleh di awal tahun ajaran baru, pembahasan yang dilakukan pada rapat semesteran ini biasanya membahas tentang evaluasi kegiatan proses belajar menagajar di semester yang lalu dan persiapan kegiatan belajar mengajar di semester yang akan datang. Rapat semesteran ini adalah suatu kegiatan mengumpulkan sekelompok orang dalam situasi tatap muka dan interaksi lisan untuk bertukar informasi atau berusaha mencapai suatu keputusan tentang masalahmasalah bersama. Kegaiatan ini berkaitan pembahasan yang berkaiatan dengan proses kegiatan belajar mengajar. Kegiatan diskusi ini dapat mengambil beberapa bentuk pertemuan, seperti panel, seminar, lokakarya, konferensi, kelompok studi, kelompok komisi, dan kegiatan lain yang bertujuan bersama-sama membicarakan dan menilai masalahmasalah tentang pendidikan dan pengajaran. Kegiatan diskusi kelompok di sekolah dapat dikembangkan melalui rapat sekolah untuk membahas bersama-sama masalah pendidikan dan pengajaran di sekolah, sehingga menghasilkan beberapa solusi yang bermanfaat untuk kemajuan (MIN) Kota Bogor.

Kegiatan selanjutnya adalah melakukan kegiatan kunjungan ke kelas, kegiatan ini berupa kegiatan obeservasi yang rutin dilakukan oleh kepala sekolah MIN Kota Bogor. Kegiatan ini dilakukan oleh kepala sekolah pada saat kegiatan berlangsung, kepala sekolah tidak langsung masuk ke ruang kelas karena dikuatirkan akan mengganggu 
kenyamanan proses belajar, kepala sekolah hanya mengawasi saja dari luar kelas. Kunjungan dan observasi kelas sangat bermanfaat untuk mendapatkan informasi tentang proses belajar-mengajar secara langsung, baik yang menyangkut kelebihan maupun kekurangan dan kelemahannya. Melalui teknik ini, kepala sekolah dapat mengamati secara langsung kegiatan guru dalam melakukan tugas utamanya, mengajar, penggunaan alat, metode, dan teknik mengajar secara keseluruhan dengan berbagai faktor yang mempengaruhinya. Hasil observasi kelas ini dapat digunakan oleh supervisor bersama guru untuk menentukan cara-cara yang paling tepat untuk memperbaiki dan meningkatkan kondisi belajarmengajar. Agar kunjungan kelas berlangsung efektif, hendaknya dipersiapkan dengan teliti dan dilaksanakan secara hati-hati dengan penampilan yang baik pula.

Program selanjutnya dalam kegiatan supervisi kepala sekolah adalah setelah melakukan supervisi di kelas, dan didapati berberapa permasalahan yang perlu disampaikan, maka setelah itu ditindaklanjuti dengan pembicaraan individual antara kepala sekolah dan guru. Sebenarnya pembicaraan individual ini dapat dilakukan tanpa harus seorang kepala sekolah melakukan kegiatan supervisi di kelas terlebih dahulu, tapi seorang guru memerlukan bantuan atau guru itu sendiri yang merasa perlu bantuan, maka segera mungkin agar mendiskusikanya dengan kepala sekolah. Pembicaraan individual merupakan salah satu alat supervisi penting karena dalam kesempatan tersebut, kepala sekolah dapat bekerja secara individual dengan guru dalam memecahkan masalah pribadi yang berhubungan dengan proses belajarmengajar, dalam realita di lapangan berdasarkan hasil wawancara dengan kepala sekolah kegiatan ini jarang sekali dilaksanakan dikarenakan kinerja guru di MIN Kota Bogor sangat memuaskan.

Kegiatan selanjutanya adalah melakukan evaluasi dari programprogram supervisi yang dilakukan oleh kepala sekolah MIN Kota Bogor, kegiatan ini biasanya dilakukan oleh kepala sekolah dan dibantu oleh wakil kepala sekolah bidang kurikulum menjelang berakhirnya kegiatan semesteran.

Berdasarkan hasil pengamatan dan wawancara terhadap para guru MIN Kota Bogor maka dapat dijelaskan bahwa dalam kegiatan supervisi yang dilakukan oleh kepala sekolah MIN 
Kota Bogor sangat berguna bagi kinerja guru sebagai pelaksana dalam kegiatan mengajar dikelas, hal ini dibuktikan dengan prestasi siswa yang cukup baik.

Di MIN Kota Bogor, kinerja para guru dapat dikatakan baik, hal ini dikarenakan kepala sekolah sering kali melakukan kegiatan supervisi terkait masalah-masalah yang ada dalam kegiatan proses belajar mengajar, kepala sekolah dapat memberikan solusi, saran, gagasan dari permasalahan yang ada. Dengan adanya supervisi itu kinerja para guru meningkat, dikarenakan merasa diperhatikan, dibimbing dan dirahkan, sehingga kinerja guru pun menjadi berkembang. Berdasarkan hasil wawancara dengan para guru salah satu cara yang masuk dalam program supervisi yang dilakukan oleh kepala sekolah MIN Kota Bogor dalam meningkatkan kinerja guru.

Dalam melaksanakan tugasnya sebagai seorang supervisor kepala sekolah MIN Kota Bogor tentunya memiliki beberapa kendala. Berdasarkan hasil wawancara dengan kepala sekolah, MIN Kota Bogor adalah sebuah lembaga pendidikan yang beberapa tahun ini baru beralih status dari madrasah swasta yang dulunya bernama Madrasah Ibtidaiyah Miftahul
Jannah yang berada di bawah Yayasan Pendidikan Miftahul Jannah kemudian diproses untuk alih status menjadi Madrasah Ibtidaiyah Negeri berdasarkan Surat Keputusan Menteri Agama Republik Indonesia Nomor 149 Tahun 2009 tentang Penetapan Madrasah Ibtidaiyah Negeri Kota Bogor pada tanggal 13 Oktober 2009, sehingga dari sini dapat disimpulkan bahwa lembaga pendidikan ini adalah lembaga baru yang dari segi pengalaman dalam mengelola lembaga pendidikan perlu adanya kerja sama yang baik antara semua pihak, hal ini dibuktikan dengan jumlah guru Pegawai Negeri Sipil (PNS) dengan guru honorer jika dipresentasikan hampir mendekati sama (55\%:45\%), sehingga kepala sekolah harus lebih giat lagi untuk membimbing dan mengarahkan (supervisi) guru-guru khususnya guru yang masih honorer yang belum tersertifikasi.

Kendala yang lainnya adalah lembaga pendidikan MIN Kota Bogor dari segi sarana prasarana kurang mendukung, seperti keberadaan MIN Kota Bogor berlokasi di daerah yang kurang strategis yaitu berada di daerah pedalaman yang padat yang hanya bisa dilalui oleh kendaraan roda dua dengan menyelusuri gang yang sempit sehingga tidak bisa dilalui oleh 
kendaraan roda empat (mobil), serta sarana lainnya masih sangat sederhana. Hal ini dibuktikan hanya memiliki enam ruang kelas, satu ruang kepala sekolah, satu ruang guru, satu ruang perpustakaan, dan tiga ruang toilet. Hal ini dapat mempengaruhi mobilitas kepala sekolah dalam melaksanakan program-program supervisi dan juga sangat mempengaruhi kinerja guru dalam melaksanakan tugas sebagai pendidik karena tidak didukung oleh sarana dan prasarana yang lengkap dan memadai.

Kendala lainnya yang sering mencul adalah selain kepala sekolah harus melaksanakan kegiatan supervisi terhadap para guru di lingkungan sekolah yang dikelolahnya, kepala sekolah juga diwajibkan untuk menghadiri rapat kedinasan dan sering sekali menghadiri undangan seminar, workshop, dan kegiatan-kegiatan lainnya sehingga kepala sekolah sering sekali meninggalkan sekolah dan akhirnya bisa menunda kegiatan supervisi yang sudah direncanakan sebelumnya. Hal ini dapat mengganggu program-program

pelaksanaan supervisi terhadap kinerja guru.

Adapun faktor-faktor pendukung dalam upaya mensukseskan kegiatan supervisi yang dilakukan oleh kepala sekolah terhadap kinerja guru adalah adanya kemauan yang kuat dari pihak guru dalam menerima bimbingan dan arahan dari kepala sekolah, karena dengan adanya keinginan yang kuat, sikap terbuka dari pihak guru maka akan terjali kerjasama yang baik dalam mensukseskan kegiatan supervisi. Faktor pendukung lainya adalah sudah terbinanya hubungan kekeluargaan dan rasa saling menghormati yang ada di lingkungan MIN Kota Bogor baik antara atasan bawahan (kepala sekolah dan para guru) maupun antar guru (teman sejawat) sehingga program-program supervisi berjalan dengan lancar dan efektif. Untuk mendukung program supervisi kepala MIN Kota Bogor selalu mengadakan kompetisi berupa pemilihan guru teladan yang diadakan setiap satu tahun ajaran yang dipilih oleh para siswa dan temen sejawat dari pihak guru MIN Kota Bogor. Kegiatan ini sangat berguna untuk memacu kinerja guru dalam mengajar di kelas sehingga berimbas kepada prestasi belajar siswa.

\section{E. KESIMPULAN}

Berdasarkan pembahasan di atas maka dapat ditarik beberapa kesimpulan, bahwa seorang kepala sekolah hendaknya senantiasa untuk selalu melakukan kegiatan supervisi yang dilakukannya kepada para guru. 
Kegiatan supervisi tersebut memiliki manfaat yang besar bagi kinerja guru dalam mengembangkan dan meningkatkan kualitas pembelajaran sehingga berdampak pada prestasi belajar siswa. Karena supervisi merupakan proses bimbingan yang dilakukan dari pihak seorang kepala sekolah kepada guru-guru yang langsung menangani proses kegiatan belajar para peserta didik, untuk memperbaiki situasi belajar-mengajar agar para peserta didik dapat belajar secara baik dan maksimal dengan tujuan prestasi belajar sesuai yang diharapkan dan dicita-citakan bersama. Disamping itu juga untuk memperbaiki situasi belajar mengajar secara efektif, disiplin, bertanggungjawab, dan memenuhi akuntabilitas. Tujuan lain dari supervisi yang dilakukan oleh kepala sekolah adalah untuk meningkatkan kualitas pembelajaran melalui pembinaan dan meningkatkan profesional guru sehingga dapat mewujudkan tujuan belajar peserta didik, supervisi juga dapat berguna bagi kepala sekolah selaku pemangku kebijakan proses pembelajaran. Karena Di dalam supervisi kepala sekolah dapat mengetahui gambaran yang jelas dan obyektif tentang situasi pendidikan, karena kepala sekolah juga dapat mengetahui faktor yang mempengaruhi situasi pendidikan dan pengajaran yang telah ditelitih sebelumnya, sehingga kepala sekolah dapat memperbaiki kelemahan dan kekurangan serta mempertahankan kondisi kondisi yang sudah baik.

Tugas kepala sekolah sebagai supervisi pendidikan adalah membina para guru agar menjadi tenaga pendidik yang profesional yang dapat melaksanakan pekerjaan dengan baik. Memberikan bimbingan dan pengarahan berkaitan dengan perencanaan pembelajaran, penggunaan media dan metode pembelajaran serta evaluasi pembelajaran. Kepala sekolah juga ketika dalam supervisi hendaknya dapat melayani guru-guru saat mereka menemui kesulitan-kesulitan berkaitan dengan materi pembelajaran. Kepala sekolah hendaknya memberikan masukan-masukan untuk peningkatan kualitas tenaga pendidik.

Kegiatan supervisi yang dilakukan oleh kepala MIN Kota Bogor dalam meningkatkan kinerja guru adalah membuat perencanaan supervisi, setelah membuat perencanaan program-program supervisi kepala sekolah membuat program-program kegiatan supervisi kepala sekolah yang ditunjukan kepada para guru untuk meningkatkan kinerja guru seperti 
kegiatan supervisi rapat semesteran, pelaksanaan supervisi kunjungan kelas dan pelaksanaan supervisi pembicaraan individual atau diskusi dengan guru berkaitan dengan permasalahan-permasalahan yang ada pada kegiatan belajar mengajar.

Adapun dalam melaksanakan supervisi kepala sekolah MIN Kota Bogor tentunya memiliki beberapa kendala yaitu jumlah guru Pegawai Negeri Sipil (PNS) dengan guru honorer jika dipresentasikan hampir sama (55\%:45\%), sehingga kepala sekolah harus lebih giat lagi untuk membimbing dan mengarahkan (supervisi) guru-guru khususnya guru yang masih honorer yang belum tersertifikasi. Kendala lainya adalah dari segi sarana prasarana kurang mendukung, seperti keberadaan MIN Kota Bogor berlokasi di daerah yang kurang strategis yaitu berada di daerah pedalaman yang padat yang hanya bisa dilalui oleh kendaraan-kendaraan yang beroda dua saja yaitu dengan menyelusuri gang yang sempit sehingga tidak bisa dilalui oleh kendaran roda empat (mobil), serta sarana lainnya masih sangat sederhana. Hal ini dapat mempengaruhi mobilitas kepala sekolah dalam melaksanakan programprogram supervisi dan juga sangat mempengaruhi kinerja guru dalam melaksanakan tugas sebagai pendidik karena tidak didukung oleh fasilatas sarana dan prasarana yang lengkap dan memadai yang ada di lembaga tersebut. Kendala lainnya yang sering muncul adalah kepala sekolah sering meninggalkan lokasi sekolah karena sering menghadiri rapat kedinasan dan sering sekali menghadiri undangan seminar, workshop dan kegiatankegiatan lainnya sehingga berdampak pada penundaan kegiatan supervisi yang sudah direncanakan sebelumnya. Hal ini dapat mengganggu programprogram pelaksanaan supervisi terhadap kinerja guru.

Adapun faktor-faktor pendukung dalam melaksanakan program-program supervisi pada MIN Kota Bogor yang dilakukan oleh kepala sekolah terhadap kegiatan guru sebagai pengajar yaitu adanya kemauan yang sangat besar dari pihak guru dalam menerima bimbingan dan arahan dari kepala sekolah, karena dengan adanya keinginan yang kuat, sikap terbuka dari pihak guru maka akan terjalin kerjasama yang baik dalam mensukseskan kegiatan supervisi, faktor lainya adalah sudah terbinanya hubungan kekeluargaan dan rasa saling menghormati yang ada di lingkungan MIN Kota Bogor baik antara 
atasan bawahan (yaitu kepala sekolah sebagai seorang atasan dan para guru sebagai seorang bawahan) maupun antar sesama dewan guru (teman sejawat) sehingga program-program supervisi berjalan dengan lancar dan efektif. Untuk mendukung program supervisi kepala MIN Kota Bogor selalu mengadakan kompetisi berupa pemilihan guru teladan yang diadakan setiap tahun ajaran yang dipilih oleh para siswa dan teman sejawat dari pihak guru MIN Kota Bogor, kegiatan ini sangat berguna untuk memacu kinerja guru dalam mengajar di kelas sehingga berimbas kepada prestasi belajar siswa MIN Kota Bogor.

\section{DAFTAR PUSTAKA}

Agus Wibowo, A. dan Hamrin. (2012). Menjadi Guru Berkarakter. Yogyakarta: Pustaka Belajar.

Asmani, JM. (2012). Tips Aplikasi Manajemen Sekolah. Jogyakarta: Diva Pres.

As-Suwaidan, TM dan Basyarahil, FU. (2005). Melahirkan Pemimpin Masa Depan. Jakarta: Gema Insani.

Asy-Syalhub, F. (2011). Begini Seharusnya Menjadi Guru. Jakarta: Darul Haq.
Charirunnisa, C. (2016). Manajemen Pendidikan dalam Multi Prespektif. Jakarta: Rajawali Pers.

Danim, S. (2015). Visi Baru Manajemen Sekolah. Jakarta: PT Bumi Askara.

Daryanto, M. (2001). Administrasi Pendidikan. Jakarta: PT Rineka Cipta.

Edy Sutrisno, E. (2017). Manajemen Sumber Daya Manusia. Jakarta: Kencana Pranada Media Grup.

Hamzah. (2011). Perencanaan Pembelajaran. Jakarta: PT Bumi Aksara.

Hermino, A. (2014). Kepemimpinan Pendidikan di Era Globalisasi. Yogyakarta: Pustaka Pelajar.

Hidayat, A. dan Machali, I. (2012). Pengolahan Pendidikan. Bandung: Kaukaba.

Jawwad, M. (2004). Menjadi Manajer Sukses. Jakarta: Gema Insani.

Kompri. (2015). Manajemen Pendidikan 1. Bandung: Alpabeta.

Mulyasa, E. (2012). Manajemen dan Kepemimpinan Kepala Sekolah. Jakarta: PT Bumi Aksara.

Ngalim, PM. (2010) Administrasi dan Supervisi Pendidikan. Bandung: PT Remaja Rosydakarya. 
Rochim, SI. (2004). Menjadi Guru yang Bisa Digugu dan Ditiru. Jakarta: Sayma Media.

Rohiat. (2012). Manajemen Sekolah. Bandung: Reflika Aditama.

Saefullah, U. (2012). Manajemen Pendidikan Islam. Bandung: CV Pustaka Setia.

Sani, RA. (2014). Inovasi Pendidikan. Jakarta: PT Bumi Aksara.

Sumidjo, W. (2002). Kepemimpinan Kepala Sekolah. Jakarta: PT RajaGrafindo Persada.

Sujanro, B. (2007) Guru Indonesia dan Perubahan Kurikulum. Jakarta: Sagung Seto.
Tabrani R., dkk. (2000). Upaya Meningkatkan

Budaya Kinerja Guru. Cianjur: CV Dinamika Karya Cipta.

Thoifuri. (2007). Menjadi Guru Inisiator. Semarang: RASAIL Media Group.

Tim Dosen UPI. (2011). Manajemen Pendidikan. Bandung: Alfabeta.

Usman, MU. (2009). Menjadi Guru Profesional. Bandung: PT Remaja Rosdakarya.

Wahab, H.S. dan Umiarso. (2011). Kepemimpinan Pendidikan dan Kecerdasan Spiritual. Jogjakarta: Ar Ruzzmedia. 